\title{
Support and Strategies for Change Among Small Patient-Centered Medical Home Practices
}

Sarab Hudson Scholle, MPH, DrPH

Stephen E. Asche, MA

Suzanne Morton, $\mathrm{MPH}^{1}$

Leif I. Solberg, $M D^{2}$

Manasi A. Tirodkar, $P b D, M S^{1}$

Carlos Roberto Jaén, $M D, P b D^{3}$

'National Committee for Quality Assurance, Washington, DC

${ }^{2}$ HealthPartners Institute for Education and Research, Minneapolis, Minnesota

${ }^{3}$ University of Texas Health Science Center at San Antonio, San Antonio, Texas

Conflicts of interest: Drs Scholle and Tirodkar and Ms Morton are employed by the National Committee for Quality Assurance, a not-for-profit organization that recognizes patient-centered medical bomes. Drs Solberg and Jaén and Mr Asche bave no conflicts of interest.

\section{CORRESPONDING AUTHOR}

Sarah Hudson Scholle, MPH, DrPH National Committee for Quality Assurance 1100 13th St NW, Ste 1000

Washington, DC 20005

scholle@ncqa.org

\begin{abstract}
PURPOSE We aimed to determine the motivations and barriers facing small practices that seek to adopt the patient-centered medical home (PCMH) model, as well as the type of help and strategies they use.

METHODS We surveyed lead physicians at practices with fewer than 5 physicians, stratified by state and level of National Committee for Quality Assurance $\mathrm{PCMH}$ recognition, using a Web-based survey with telephone, fax, and mail follow-up. The response rate was 59\%, yielding a total sample of 249 practices from 23 states.
\end{abstract}

RESULTS Improving quality and patient experience were the strongest motivations for PCMH implementation; time and resources were the biggest barriers. Most practices participated in demonstration projects or received financial rewards for $\mathrm{PCMH}$, and most received training or other kinds of help. Practices found training and help related to completing the PCMH application to be the most useful. Training for patients was both less common and less valued. The most commonly used strategies for practice transformation were staff training, systematizing processes of care, and quality measurement/goal setting. The least commonly endorsed strategy was involving patients in quality improvement. Practices with a higher level of PCMH recognition were more likely to have electronic health records, to report barriers, and to use measurement-based quality improvement strategies.

CONCLUSIONS To spread the adoption of the PCMH model among small practices, financial support, practical training, and other help are likely to continue to be important. Few practices involved patients in their implementation, so it would be helpful to test the impact of greater patient involvement in the $\mathrm{PCMH}$.

Ann Fam Med 2013;11:S6-S13. doi:10.1370/afm.1487

\section{INTRODUCTION}

卫 he patient-centered medical home $(\mathrm{PCMH})$ is an integral component of health care reform, and a growing number of public- and private-sector $\mathrm{PCMH}$ demonstration projects are under way across the country. Although data on the impact of the PCMH on outcomes and costs of care are still limited, ${ }^{1}$ some key programs have reported positive effects for quality and reductions in key high-cost services such as emergency department visits. ${ }^{2,3}$

The likelihood that the PCMH model will become the standard approach to primary care in the United States depends on its uptake by small practices. Although small, independently owned practices with 5 physicians or fewer provide the bulk of ambulatory care in the United States ${ }^{4}$ they are less likely than larger practices to be using medical home strategies such as care coordination, enhanced access, and team-based care. ${ }^{5}$ The use of systems for quality improvement (QI) is a particular 
challenge: a national survey of small and mediumsized practices (1-19 physicians) found that few make use of established techniques: only $10 \%$ participated in QI collaboratives, $10 \%$ used a rapid cycle QI strategy, $18 \%$ collected data from electronic records for quality measurement, and $19 \%$ gave performance feedback to physicians. ${ }^{5}$

Little is known about successful strategies for implementing the PCMH model (or other QI efforts) in small practices. Solberg ${ }^{6}$ argues that practice transformation requires 3 components: that the practice makes it a priority to improve quality, promotes a culture and implements clear steps for change, and adopts care processes that support improvement. Factors internal to the practice as well as aspects of the external context and health care marketplace can facilitate or block these efforts to improve. ${ }^{7}$ Most of the research on QI methods has occurred in larger organizations. ${ }^{8,9}$ Berenson et $\mathrm{al}^{8}$ noted that small practices seeking to implement the PCMH model face particular challenges because of inadequate resources (eg, bearing the cost of investing in health information technology or specialized staff such as diabetes educators) as well as the difficulty of making changes in the face of ongoing patient care responsibilities. A number of factors internal and external to a practice have been shown to affect implementation of QI systems and achievement of high performance. These factors include both capabilities of the practice such as leadership, teamwork, focus on change, and commitment to accountability, as well as adoption of specific strategies for change (eg, use of rapid cycle testing or performance feedback). ${ }^{10-12}$ Several reports have argued that technical assistance is needed to help practices through these changes by introducing a framework for change, exposing staff to new ideas, and providing opportunities for peer exchange, although little is known about the types of assistance actually provided or used. ${ }^{13-15}$

Given the growing expectations for small practices to adopt the PCMH model and implement electronic health records, there is a critical need to understand the kinds of strategies and supports that help such practices to achieve successful implementation. We surveyed small practices that achieved different levels of recognition as a PCMH under the National Committee for Quality Assurance (NCQA) Physician Practice Connections' Patient-Centered Medical Home program. We describe here the motivations and barriers they faced, the type of help they received and valued, and the strategies they used as they implemented the PCMH. In addition, we explore how these characteristics and experiences differed between practices with different levels of PCMH implementation, based on the NCQA recognition level.

\section{METHODS}

\section{Sampling Approach}

NCQA identified a sample of small practices (those having $<5$ physicians) with the Physician Practice Connections' Patient-Centered Medical Home recognition. ${ }^{16}$ NCQA defines a practice as a single geographic site that shares medical records and key office systems. To be considered for recognition, practices voluntarily complete a Web-based questionnaire and attach documentation to support their responses. Trained surveyors review the documentation, and 5\% of applications undergo on-site audit. All applications undergo 3 rounds of internal review. Practices could achieve 3 levels of recognition based on the total score as well as their performance on 10 "must pass" elements. On July 15,2011 , when we selected our study sample, there were 2,418 recognized practices: $30.2 \%$ were Level 1 , $4.3 \%$ were Level 2, and $65.5 \%$ were Level 3.

To be able to make comparisons between levels of recognition across a number of states, we stratified the sample by Level 1 and 3 (dropping the small number of Level 2 practices). We included only states having both Level 1 and Level 3 recognized practices, and decreased the sampling weight for 2 states with very large numbers of recognized practices (New York and Pennsylvania), so that they did not have greater representation than the distribution of practices nationally. We surveyed the lead physician at the practice; where that was not documented or the practice indicated there was not a single lead physician, we randomly selected a physician.

Of the 2,418 recognized practices, 915 were excluded because they had 5 or more physicians or did not have any physicians. Another 202 practices were excluded because they did not provide primary care services to adult patients, and 59 of the remaining practices were excluded for having Level 2 recognition. Of the 1,242 eligible practices on July 15, 2011, we selected a random sample of 430 practices (split between Levels 1 and 3) for surveying. Twenty-three practices that we later discovered had closed or merged with other practices were replaced randomly. Nine practices that no longer met the definition of small on the basis of data collected after selection or survey completion were excluded.

Practices received a gift basket for participation. The study was reviewed, approved, and monitored by Chesapeake Research Review Inc, an independent, accredited institutional review board.

\section{Survey Methods}

NCQA recognition program staff sent e-mail notification about the survey to the identified practice physician, with a link to a Web-based questionnaire. Non- 
respondents received additional e-mail reminders, as well as a paper copy of the questionnaire by mail, and multiple attempts at fax or telephone follow-up.

\section{Variables}

The questionnaire was developed using insights from in-depth case studies conducted in $6 \mathrm{PCMH}$-recognized small practices. The questionnaire items were revised on the basis of pretesting and cognitive interviews.

To assess practice priorities, we adapted a single item rating on a 10 -point scale used in previous studies to assess the priority for QI to address priority for making the practice more of a PCMH. ${ }^{9}$ Higher ratings indicated higher priority.

We adapted items assessing motivations and barriers for QI used in the National Survey of Physician Organizations. ${ }^{5}$ For motivations, we asked respondents to rate the importance of 6 factors in the practice's decision to seek NCQA recognition as a PCMH on a 5-point scale $(1=$ not at all to $5=$ very important). We also asked practices to report on the extent to which 6 factors were barriers to implementation of the PCMH model also on a 5 -point scale $(1=$ no barrier to $5=$ great barrier).

We asked respondents if they had ever been involved in a demonstration project, pilot project, or other program including those sponsored by state, federal, or health plan entities, or in other initiatives. We also inquired about whether practices received any type of payment for being a PCMH (eg, enhanced fee-for-service remuneration, monthly payments, performance incentives).

Respondents reported whether their practice received any type of help when implementing the $\mathrm{PCMH}$ and how useful this help was (very, somewhat, or not at all) for their practice.

Finally, to determine strategies and capabilities for practice change, we used the Change Process Capability Questionnaire (CPCQ) of Solberg et $\mathrm{al}^{9}$ to assess strategies used to implement the $\mathrm{PCMH}$ as well as aspects of organizational culture. Those investigators showed that the CPCQ distinguishes among medical groups and is associated with both change priorities and implemented systems for depression. ${ }^{9}$ The strategies scale includes 18 items. The composite is a sum of items rated "yes, worked well" (1 point), "yes, did not work well" (0.5 point), and "no" (0 points). The CPCQ has 14 items addressing capabilities for change; the score is a sum of items rated 4 or 5 on scale from 1 (strongly disagree) to 5 (strongly agree).

\section{Analysis}

We present descriptive analyses of individual items and composites. We explored associations between level of recognition and practice type using contingency tables and Pearson $\chi^{2}$ tests for categorical survey variables. For continuous items and composite scores, associations were tested with independent samples $t$ tests. We did not make any adjustment for multiple comparisons. The study was planned with a recruitment sample size of 430 that was expected to attain 300 completed questionnaires at a $70 \%$ response rate in order to achieve $80 \%$ power $(\alpha=.05,2$-sided tests) to detect a difference by level of $25 \%$ vs $40 \%$ for binary questionnaire items and a difference in means by Level 1 vs 3 of the Cohen $d$ of 0.3 for continuously scored survey items.

\section{RESULTS}

\section{Study Group}

Of the 421 eligible practices randomized that met eligibility criteria at the end of the study, 249 practices $(59.1 \%)$ in 23 states responded. The respondents included 91 Level 1 practices, 125 Level 3 practices, and 33 practices that changed from Level 1 to Level 3 between the time of sampling and completion of the survey period. Because this group that changed generally showed greater resemblance to Level 3 practices, we combined these 2 groups in our analysis. We found no significant differences in response based on practice size or recognition level. Table 1 shows characteristics of the practices and the responding physicians. Level 3 practices were more likely to have a fully electronic health record; the respondents for Level 3 practices were more likely to have graduated from medical school more recently than those in Level 1 practices.

\section{Priorities, Motivators, and Barriers}

As shown in Table 2, less than one-third of practices rated $\mathrm{PCMH}$ implementation as a very high priority. Improving quality and patient experiences were the strongest motivators for PCMH implementation (across all levels). Time and resources were the biggest barriers, and compared with Level 3 practices, Level 1 practices rated these factors and information systems as significantly greater barriers.

\section{Demonstration Projects, Payment, and Help With PCMH Implementation}

More than $75 \%$ of the practices participated in demonstration or pilot projects or received financial rewards for PCMH, and almost one-half (45.4\%) did both (Table 3 ). The large majority of practices received training for staff $(85.5 \%)$ or clinicians $(84.2 \%)$. More than one-half of these practices received consultation specific to their practice $(63.9 \%)$ or access to a learning collaborative (59.3\%). Most practices received training on how to meet NCQA's recognition requirements $(81.3 \%)$ or help with preparing their applica- 


\section{Table 1. Characteristics of Practices and Responding Physicians}

\begin{tabular}{|c|c|c|c|}
\hline \multirow[b]{2}{*}{ Characteristic } & \multirow[b]{2}{*}{$\begin{array}{l}\text { Overall } \\
(\mathrm{N}=249)\end{array}$} & \multicolumn{2}{|c|}{ Recognition Level } \\
\hline & & $\begin{array}{l}\text { Level } 1 \\
(\mathrm{n}=91)\end{array}$ & $\begin{array}{l}\text { Level } 3^{a} \\
(n=158)\end{array}$ \\
\hline \multicolumn{4}{|l|}{ Practice } \\
\hline Solo physician practice, \% & 34.9 & 40.7 & 31.7 \\
\hline Physicians/NPs/PAs, mean (SD), No. & $2.9(1.6)$ & $2.7(1.6)$ & $3.0(1.5)$ \\
\hline $\begin{array}{l}\text { Total staff (excluding physicians/NPs/PAs), } \\
\text { mean (SD), No. }\end{array}$ & $8.2(5.0)$ & $7.6(4.8)$ & $8.5(5.1)$ \\
\hline \multicolumn{4}{|l|}{ Practice type, \% } \\
\hline $\begin{array}{l}\text { Federally designated health center or com- } \\
\text { munity health center }\end{array}$ & 14.9 & 14.3 & 15.2 \\
\hline Physician owned, independent & 20.9 & 28.5 & 16.5 \\
\hline Physician owned, affiliated with larger group & 27.7 & 23.1 & 30.4 \\
\hline Hospital/health system owned & 36.5 & 34.1 & 38.0 \\
\hline \multicolumn{4}{|l|}{ Region, \% } \\
\hline New England (CT, ME, MA, NH, RI, VT) & 24.1 & 28.6 & 21.5 \\
\hline Northeast (NY, NJ) & 13.7 & 17.6 & 11.4 \\
\hline Mid-Atlantic (DC, MD, PA, VA, WV) & 10.4 & 15.4 & 7.6 \\
\hline Southeast (AL, FL, GA, KY, MS, NC, SC, TN) & 20.1 & 12.1 & 24.7 \\
\hline Midwest (IL, IN, MI, MN, OH, WI) & 18.1 & 15.4 & 19.6 \\
\hline Southwest (AR, LA, NM, OK, TX) & 7.2 & 8.8 & 6.3 \\
\hline Plains (IA, KS, MO, NE) & 2.8 & 2.2 & 3.2 \\
\hline Mountain (CO, MT, ND, SD, UT, WY $)$ & 3.2 & 0.0 & 5.1 \\
\hline West $(A Z, C A, H I, N V)$ & 0.4 & 0.0 & 0.6 \\
\hline Northwest (AK, ID, OR, WA) & 0.0 & 0.0 & 0.0 \\
\hline Fully electronic health record, $\%^{\mathrm{b}}$ & 79.6 & 67.5 & 86.2 \\
\hline \multicolumn{4}{|l|}{ Physician } \\
\hline Female, \% & 35.0 & 33.3 & 36.0 \\
\hline \multicolumn{4}{|l|}{ Race/ethnicity, \%c } \\
\hline White, non-Hispanic & 78.6 & 80.2 & 77.7 \\
\hline Black, non-Hispanic & 6.0 & 10.5 & 3.4 \\
\hline Asian, non-Hispanic & 9.8 & 8.1 & 10.8 \\
\hline Hispanic & 4.7 & 1.2 & 6.8 \\
\hline Other/mixed & 0.9 & 0.0 & 1.3 \\
\hline Time in this practice, mean (SD), y & $13.9(9.0)$ & $14.8(9.9)$ & $13.3(8.5)$ \\
\hline $\begin{array}{l}\text { Time since graduation from medical school, } \\
\text { mean (SD), } y^{c}\end{array}$ & $23.4(9.6)$ & $25.5(9.7)$ & $22.2(9.4)$ \\
\hline \multicolumn{4}{|l|}{$\mathrm{NP}=$ nurse practitioner; $\mathrm{PA}=$ physician assistant. } \\
\hline \multicolumn{4}{|c|}{ Note: Pearson $x^{2}$ test for categorical variables and independent samples $t$ tests for continuous variables. } \\
\hline \multicolumn{4}{|c|}{$\begin{array}{l}\text { Includes practices that entered the study at Level } 3 \text { and practices that advanced from Level } 1 \text { to Level } 3 \\
\text { during the study. } \\
\text { b } P<.01 \text {, difference by level. } \\
\text { c } P<.05 \text {, difference by level. }\end{array}$} \\
\hline
\end{tabular}

least commonly endorsed strategies were involving patients in $\mathrm{QI}$ and using formal QI strategies. Only $15.5 \%$ of practices said they included patients on QI committees or teams. Many practices reported using some elements of QI methods but seemed not to recognize them as such (eg, 50\% said they used pilot testing of new methods, but only $30 \%$ said they used formal methods). Compared with Level 1 practices, Level 3 practices scored significantly higher on the CPCQ strategies scale $(P=.01)$ and were more likely to use measurementbased strategies such as pilot testing or providing feedback to clinicians.

High ratings of organizational change ability were seen in the areas of clinicians adhering to practice policies, leaders showing enthusiasm for QI, and clinicians espousing a shared mission (Table 5). Lower ratings were seen in the areas of receiving feedback from patients about benefit from changes, practices prioritizing quality of care over finances, and practice operations relying on organized systems. Level 3 practices showed more capability for practice change in the areas of enthusiastic leadership for care, use of organized systems, and availability of resources for quality improvement.

\section{DISCUSSION}

\section{Key Findings}

This is the first study to examine transformation help and strategies among a national sample of tion $(81.0 \%)$; they also rated such help related to the recognition program as most useful. Level I practices were more likely to receive training about NCQA recognition requirements. Training and engagement in improvement for patient representatives or partners was both much less common and less valued.

\section{Practice Change Strategies and Ability}

The most commonly used strategies for practice transformation were developing systems for care, training, and quality measurement/goal setting (Table 4 ). The small practices that have independent documentation of PCMH implementation. Of these 249 practices in 23 states, the large majority are participating in demonstration projects or receiving financial rewards for using the PCMH model, and most have received training or other kinds of help. Some demonstration projects require obtaining NCQA recognition for participation. We found some key differences between Level 3 and Level 1 practices-primarily in the availability of fully electronic health records, the types of barriers reported, strategies used for QI, and in 


\begin{tabular}{|c|c|c|c|}
\hline \multirow[b]{2}{*}{ Change Driver } & \multirow[b]{2}{*}{$\begin{array}{l}\text { Overall } \\
(\mathrm{N}=249)\end{array}$} & \multicolumn{2}{|c|}{ Recognition Level } \\
\hline & & $\begin{array}{l}\text { Level } 1 \\
(\mathrm{n}=91)\end{array}$ & $\begin{array}{l}\text { Level } 3^{a} \\
(n=158)\end{array}$ \\
\hline $\begin{array}{l}\text { Priority for "making practice more of a } \\
\text { patient-centered medical home,"b \% }\end{array}$ & 29.8 & 24.4 & 32.9 \\
\hline \multicolumn{4}{|l|}{ Motivations for $\mathrm{PCMH}$, mean (SD) rating } \\
\hline To improve quality of patient care & $4.4(0.9)$ & $4.3(1.0)$ & $4.4(0.9)$ \\
\hline To improve patient experiences of care & $4.4(0.9)$ & $4.3(1.3)$ & $4.4(0.8)$ \\
\hline To function more efficiently & $4.1(1.2)$ & $4.1(1.1)$ & $4.0(1.2)$ \\
\hline To become eligible for financial incentives & $4.0(1.1)$ & $4.1(1.1)$ & $3.9(1.1)$ \\
\hline $\begin{array}{l}\text { To meet expectations/requirements set by } \\
\text { our medical group or delivery system }\end{array}$ & $3.9(1.2)$ & $4.0(1.2)$ & $3.9(1.3)$ \\
\hline To improve clinician experience & $3.6(1.3)$ & $3.5(1.4)$ & $3.6(1.3)$ \\
\hline $\begin{array}{l}\text { To meet expectations/requirements from } \\
\text { my specialty society or board }\end{array}$ & $2.8(1.5)$ & $3.0(1.4)$ & $2.7(1.5)$ \\
\hline \multicolumn{4}{|l|}{$\begin{array}{l}\text { Barriers to } \mathrm{PCMH} \text { implementation, } \\
\text { mean (SD) rating }\end{array}$} \\
\hline Time $^{d}$ & $3.7(1.2)$ & $3.9(1.2)$ & $3.6(1.2)$ \\
\hline $\begin{array}{l}\text { Money and other resources to invest } \\
\text { in staff, training, or equipmente }\end{array}$ & $3.3(1.3)$ & $3.6(1.3)$ & $3.1(1.3)$ \\
\hline Information systems ${ }^{d}$ & $2.7(1.3)$ & $3.0(1.4)$ & $2.5(1.3)$ \\
\hline Knowledge and experience & $2.5(1.1)$ & $2.7(1.2)$ & $2.4(1.1)$ \\
\hline Clinician/staff resistance to change & $2.4(1.2)$ & $2.5(1.2)$ & $2.3(1.2)$ \\
\hline Clinician/staff turnover & $1.9(1.2)$ & $1.8(1.3)$ & $2.0(1.2)$ \\
\hline \multicolumn{4}{|l|}{ PCMH = patient-centered medical home. } \\
\hline $\begin{array}{l}\text { Note: Pearson } x^{2} \text { test for categorical variables and in } \\
\text { a Includes practices that entered the study at Level } 3 \\
\text { during the study. } \\
\text { b Rating of } 9 \text { or } 10 \text { on scale of } 0 \text { to } 10 \text {. } \\
\text { ' Range: } 1 \text { to } 5 \text {, with higher ratings indicating great } \\
\text { d } P<.05 \text {, difference by level. } \\
\text { e } P<.01 \text {, difference by level. }\end{array}$ & $\begin{array}{l}\text { ependent sampl } \\
\text { nd practices tha } \\
\text { barrier. }\end{array}$ & $\begin{array}{l}\text { tests for cont } \\
\text { vanced from L }\end{array}$ & $\begin{array}{l}\text { uous variables. } \\
\text { vel } 1 \text { to Level }\end{array}$ \\
\hline
\end{tabular}

most practices did not view PCMH implementation as the highest priority compared with other priorities such as financial goals, QI, or implementing meaningful use requirements for electronic health records.

Second, practices placed the greatest value on tangible supports. Although most practices received training for clinicians and staff, and many also received consultation or access to collaborative support, the type of help they valued the most was training and support related to the NCQA application process. This finding suggests that practices appreciate training directed toward specific goals and help with meeting the requirements for external review more than more general types of assistance.

Third, the use of QI strategies among PCMH-recognized practices highlights the differences between these practices and other small practices. Compared with small practices in the survey by Rittenhouse et $\mathrm{al}_{1}{ }^{5}$ a larger proportion of PCMH-recognized practices in our survey used rapid cycle QI (51.4\% vs $10.2 \%$ ) and gave performance feedback to physicians $(60.3 \%$ vs $18.9 \%)$. These strategies also distinguish practices with

particular, the use of measurement-based strategies, On other topics, including priority and motivation for $\mathrm{PCMH}$ implementation, types of support received, and organizational capabilities for change, practices with different degrees of PCMH implementation were similar. These findings shed light on the strategies that are important to PCMH implementation and suggest the types of support that all small practices need for the "epic whole-practice reimagination and redesign" that PCMH transformation requires. ${ }^{13}$

First, small practices that have achieved recognition did so in the presence of and likely because of local demonstration projects, financial incentives, and various supports for change. After the desire to improve quality and patient experiences, and improve efficiency, respondents reported that the availability of financial incentives was the strongest motivator to change. Time, resources, and information systems were reported to be barriers for all practices but particularly for Level 1 practices-suggesting that addressing these barriers is critical for helping practices to seek higher levels of PCMH implementation. Importantly,
Level 3 vs Level 1 PCMH recognition. Although the use of a fully electronic health record is not specifically required for $\mathrm{PCMH}$ recognition, the greater use of these records may support these QI strategies and other activities of the PCMH such as care coordination and population management.

Fourth, most PCMH-recognized practices have yet to engage patients as partners in transformation efforts. Although 30\% of practices said they had trained clinicians and staff on involving patients or consumer advocates, only $15 \%$ of practices included patients on QI teams. Along with the lower value ascribed to patient training, it appears that $\mathrm{PCMH}$ practices may need more help in navigating the practi-

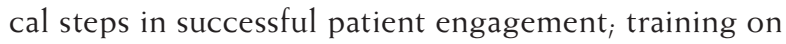
how to work with patients and consumer representatives in QI may need to happen before actual training for the patients and advocates. Moreover, practices may need more convincing evidence or experience about the link between patient engagement in QI efforts and achieving their key motivations of improving quality and patient experiences. ${ }^{17}$ 


\begin{tabular}{|c|c|c|c|}
\hline \multirow[b]{2}{*}{ Measure } & \multirow[b]{2}{*}{$\begin{array}{l}\text { Overall } \\
(\mathrm{N}=249)\end{array}$} & \multicolumn{2}{|c|}{ Recognition Level } \\
\hline & & $\begin{array}{l}\text { Level } 1 \\
(n=91)\end{array}$ & $\begin{array}{l}\text { Level } 3^{a} \\
(n=158)\end{array}$ \\
\hline \multicolumn{4}{|l|}{$\begin{array}{l}\text { Participate in demonstration/pilot project and/or } \\
\text { received payment for being PCMH, \% responding yes }\end{array}$} \\
\hline Did not participate in a project or receive payment & 21.7 & 14.3 & 26.0 \\
\hline Participated in project only & 8.8 & 11.0 & 7.6 \\
\hline Received payment for $\mathrm{PCMH}$ only & 24.1 & 33.0 & 19.0 \\
\hline Both participated and received PCMH payment & 45.4 & 41.8 & 47.5 \\
\hline \multicolumn{4}{|l|}{ Received help for PCMH implementation, \% yes } \\
\hline Training for staff & 85.5 & 81.8 & 87.7 \\
\hline Training for clinicians & 84.2 & 82.0 & 85.4 \\
\hline Training for patients/consumer advocates & 31.4 & 28.4 & 33.1 \\
\hline Consultation/coaching/facilitation specific to practice & 63.9 & 61.6 & 65.2 \\
\hline Access to a learning collaborative & 59.3 & 55.7 & 61.4 \\
\hline $\begin{array}{l}\text { Training on how to meet NCQA's recognition } \\
\text { requirements }\end{array}$ & 81.3 & 87.8 & 77.6 \\
\hline $\begin{array}{l}\text { Assistance with preparing documentation of applica- } \\
\text { tion requirements for NCQA's recognition program }\end{array}$ & 81.0 & 86.5 & 77.8 \\
\hline \multicolumn{4}{|l|}{ Of those who received help, $\%$ who found it very useful } \\
\hline Training for staff & 43.5 & 44.4 & 43.0 \\
\hline Training for clinicians & 41.1 & 38.4 & 42.5 \\
\hline Training for consumer advocates & 31.6 & 20.0 & 37.3 \\
\hline $\begin{array}{l}\text { Consultation/coaching/facilitation specific to your } \\
\text { practice }\end{array}$ & 47.4 & 52.8 & 44.6 \\
\hline Access to a learning collaborative & 43.4 & 51.0 & 39.4 \\
\hline $\begin{array}{l}\text { Training on how to meet NCQA's recognition } \\
\text { requirements }\end{array}$ & 52.5 & 50.6 & 53.7 \\
\hline $\begin{array}{l}\text { Assistance with preparing documentation of applica- } \\
\text { tion requirements for NCQA's recognition program }\end{array}$ & 67.4 & 63.6 & 69.8 \\
\hline \multicolumn{4}{|c|}{ NCQA = National Committee for Quality Assurance; PCMH = patient-centered medical home. } \\
\hline \multicolumn{4}{|l|}{ Note: Differences calculated with the Pearson $x^{2}$ test. } \\
\hline \multicolumn{4}{|c|}{$\begin{array}{l}\text { a Includes practices that entered the study at Level } 3 \text { and practices that advanced from Level } 1 \text { to Level } 3 \text { during } \\
\text { the study. } \\
\text { b } P<.05 \text {, difference by level. }\end{array}$} \\
\hline
\end{tabular}

Finally, the large proportion of Level 1 practices that switched to Level 3 recognition suggest that many PCMH practices are on a continuing journey of transformation. More than one-quarter of Level 1 practices switched during our time frame, and many of the Level 3 practices in this study had previously upgraded from Level 1 before the study. This finding demonstrates that practices are able to successfully navigate the roadmap to greater PCMH implementation.

The Supplemental Appendix (available online at

http://annfammed.org/content/11/Suppl_1/S6/

suppl/DC1) details some of the contextual factors

that my have influenced our findings and that others may wish to consider when undertaking PCMH initiatives in small practices.

\section{Study Limitations}

Several limitations affect the generalizability of our findings. Only $59 \%$ of practices responded to this survey. This response rate may affect the representativeness of the results, but we did not detect any differences between those that did or did not respond on the basis of characteristics that we could test (number of physicians, number of employees, and recognition level). It would be preferable to gain perspectives from multiple clinicians or staff on some topics ${ }_{i}$ however, our resources allowed for only 1 respondent per practice. Only practices that have NCQA recognition were included. Several other organizations and states qualify practices as medical homes; however, NCQA's program is the largest program, representing nearly 24,000 clinicians. Our study may not be representative of all NCQArecognized practices because we sought to ensure the ability to compare Level 1 and Level 3 practices. The size of these practices may vary because we used the number of physicians as a determinant of practice size rather than the number of clinicians. In addition, we were unable to include practices led by nurse practitioners or physician assistants because we did not have consistent information about those practices in the NCQA data. Despite these limitations, this survey is the first to look across nearly one-half of US states at transformation experiences of small practices where there is independent confirmation of their PCMH implementation.

\section{Implications}

Small practices that have achieved recognition as PCMHs generally do so in the context of financial incentives and other supports. To further spread the adoption of the PCMH model, these efforts are likely to continue to be important. Practices value training and help that answers immediate needs; finding ways to make training more useful and oriented to daily work of practices is important. These practices infrequently included patients in their QI efforts. Policy makers who design demonstration projects 


\section{Table 4. Strategies for Practice Change}

\begin{tabular}{|c|c|c|c|}
\hline \multirow[b]{2}{*}{ Strategy } & \multirow[b]{2}{*}{$\begin{array}{l}\text { Overall } \\
(\mathrm{N}=249)\end{array}$} & \multicolumn{2}{|c|}{ Recognition Level } \\
\hline & & $\begin{array}{l}\text { Level } 1 \\
(n=91)\end{array}$ & $\begin{array}{l}\text { Level } 3^{a} \\
(\mathrm{n}=158)\end{array}$ \\
\hline \multicolumn{4}{|l|}{ Use of specific strategies, \% reporting that it worked well } \\
\hline Changing or creating systems in the practice that make it easier to provide high-quality care & 86.5 & 82.2 & 89.0 \\
\hline Providing information and skills training to clinicians and staffb & 79.0 & 70.3 & 84.1 \\
\hline Designing care improvements to make the care process more beneficial to the patient & 78.9 & 82.4 & 76.7 \\
\hline Periodically measuring care quality to assess compliance with any new approach to care & 76.0 & 72.2 & 78.2 \\
\hline Setting goals and benchmarking rates of performance quality & 73.6 & 71.1 & 75.0 \\
\hline Including front-line staff on quality improvement committees or teams & 69.1 & 65.9 & 71.0 \\
\hline Removing or reducing barriers to better quality of care & 65.6 & 63.3 & 66.9 \\
\hline $\begin{array}{l}\text { Providing to those who are charged with implementing improved care the power to authorize and } \\
\text { make the desired changes }\end{array}$ & 64.9 & 55.6 & 70.3 \\
\hline $\begin{array}{l}\text { Delegating to nonclinician staff the responsibility to carry out aspects of care that were the responsi- } \\
\text { bility of clinicians }{ }^{b}\end{array}$ & 63.9 & 55.6 & 68.8 \\
\hline Organizing people into teams focused on accomplishing the change process for improved care & 60.9 & 58.0 & 62.6 \\
\hline Reporting measurements of individual clinician performance for comparison with peer clinicians ${ }^{c}$ & 60.3 & 48.9 & 66.9 \\
\hline Using opinion leaders or role modeling or other strategies to encourage support for changes & 57.3 & 54.4 & 59.0 \\
\hline $\begin{array}{l}\text { Using piloting or pretesting of changes and evaluating the impact before introducing practicewide } \\
\text { changesc }^{c}\end{array}$ & 51.4 & 38.2 & 59.0 \\
\hline Designing care improvements to make physician participation less work than before ${ }^{b}$ & 46.9 & 38.9 & 51.6 \\
\hline Providing training to clinicians and staff on how to involve patients/families in quality improvement & 30.1 & 27.4 & 31.6 \\
\hline $\begin{array}{l}\text { Using formal quality improvement or efficiency approaches (eg, Lean, Plan-Do-Study-Act, rapid } \\
\text { cycles, Six Sigma, Model for Improvement) }\end{array}$ & 30.5 & 26.7 & 32.9 \\
\hline Including patients on quality improvement committees or teams & 15.5 & 12.1 & 17.5 \\
\hline Overall score, mean $(S D)^{b}$ & $\begin{array}{l}11.5 \\
(3.8)\end{array}$ & $\begin{array}{l}10.7 \\
(4.1)\end{array}$ & $\begin{array}{l}11.9 \\
(3.5)\end{array}$ \\
\hline \multicolumn{4}{|l|}{ Note: Pearson $x^{2}$ test for categorical variables and independent samples $t$ tests for continuous variables. } \\
\hline \multicolumn{4}{|l|}{ 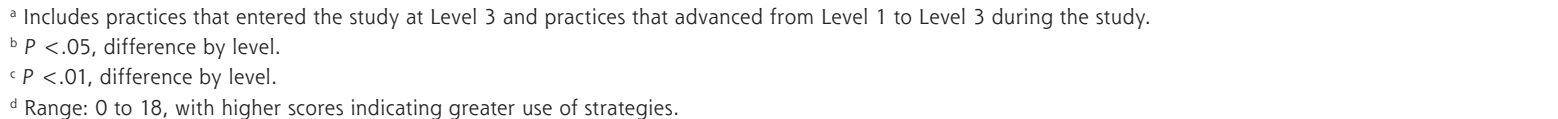 } \\
\hline
\end{tabular}

\section{Table 5. Items Assessing Organizational Change Ability}

\begin{tabular}{|c|c|c|c|}
\hline \multirow[b]{2}{*}{ Item } & \multirow[b]{2}{*}{$\begin{array}{l}\text { Overall } \\
(\mathrm{N}=249)\end{array}$} & \multicolumn{2}{|c|}{ Recognition Level } \\
\hline & & $\begin{array}{l}\text { Level } 1, \% \\
(n=91)\end{array}$ & $\begin{array}{l}\text { Level } 3, \text { a } \% \\
(n=158)\end{array}$ \\
\hline The clinicians in our practice adhere to practice policies. & 83.3 & 82.2 & 83.9 \\
\hline The leaders of our efforts to improve care quality are enthusiastic about their task. ${ }^{b}$ & 82.3 & 74.4 & 86.7 \\
\hline The clinicians in our practice espouse a shared mission and policies. & 79.8 & 75.8 & 82.1 \\
\hline $\begin{array}{l}\text { The working environment in our practice is collaborative and cohesive, with a shared sense of pur- } \\
\text { pose, cooperation, and willingness to contribute to the common good. }\end{array}$ & 77.4 & 76.9 & 77.1 \\
\hline $\begin{array}{l}\text { When making changes at our practice, we choose new processes of care that are more advantageous } \\
\text { than the old for everyone involved (patients, clinicians, and our entire practice). }\end{array}$ & 68.7 & 71.1 & 67.3 \\
\hline The thinking of our leadership is strongly oriented toward systems. & 68.0 & 61.1 & 72.1 \\
\hline We have greatly improved the quality of care in the past year. & 67.3 & 61.1 & 70.9 \\
\hline We have many clinician and staff champions interested in leading the improvement of care quality. & 64.2 & 58.4 & 67.5 \\
\hline $\begin{array}{l}\text { Most of the other health care resources in our community (hospitals, community groups, specialist } \\
\text { offices) are supportive of the medical home concept. }\end{array}$ & 59.5 & 59.6 & 59.5 \\
\hline Our practice operations rely heavily on organized systems. ${ }^{b}$ & 58.5 & 48.9 & 64.1 \\
\hline Our practice attaches more priority to quality of care than to finances. & 57.7 & 62.5 & 55.1 \\
\hline We have received feedback from patients that they have benefited from the changes we have made. & 56.5 & 53.3 & 58.2 \\
\hline Our practice is undergoing considerable stress as the result of internal changes. (reverse coded) & 41.9 & 47.2 & 38.9 \\
\hline $\begin{array}{l}\text { Our resources (personnel, time, financial) are too tightly limited to improve care quality now. } \\
\text { (reverse coded) }\end{array}$ & 21.1 & 28.1 & 17.2 \\
\hline Overall score, mean $(S D)^{b, c}$ & $\begin{array}{l}9.5 \\
(3.0)\end{array}$ & $\begin{array}{l}9.0 \\
(3.2)\end{array}$ & $\begin{array}{l}9.8 \\
(2.8)\end{array}$ \\
\hline \multicolumn{4}{|c|}{ Note: Values are percentage that agree or strongly agree. Pearson $x^{2}$ test for categorical variables and independent samples $t$ tests for continuous variables. } \\
\hline \multicolumn{4}{|c|}{$\begin{array}{l}\text { a Includes practices that entered the study at Level } 3 \text { and practices that advanced from Level } 1 \text { to Level } 3 \text { during the study. } \\
\text { b } P<.05 \text {, difference by level. } \\
\text { ' Range: } 1 \text { to } 14 \text {, with higher scores indicating greater change ability. }\end{array}$} \\
\hline
\end{tabular}


and organizations that qualify practices as PCMHs should consider how to balance incentives for practices to organized systems as well as to promote patient engagement. Research is needed to demonstrate and identify the most successful ways to engage patients in PCMH implementation.

To read or post commentaries in response to this article, see it online at http://www.annfammed.org/content/11/Suppl_1/S6.

Key words: patient-centered medical home; primary care; quality improvement; change management; practice-based research

Submitted September 17, 2012; submitted, revised, November 22, 2012; accepted November 29, 2012

Funding support: This study was funded by the Agency for Healthcare Research and Quality grant 1R18HS019162-01.

Disclaimer: The content is solely the responsibility of the authors and does not necessarily represent the official views of the Agency for Healthcare Research and Quality.

Acknowledgments: We thank the physicians who took time from their busy schedules to complete this questionnaire, staff at NCQA and HealthPartners Institute for Education and Research, for assisting in data collection and analyses, and the consultants who guided our work.

\section{References}

1. Williams JW, Jackson GL, Powers BJ, et al. The Patient- Centered Medical Home. Closing the Quality Gap. Vol 2. Evidence Report/ Technology Assessment No. 208. (Prepared by the Duke Evidence-based Practice Center under Contract No. 290-2007-10066-I.) Rockville, MD: Agency for Healthcare Research and Quality; 2012. AHRQ publication 12-E008- EF. http://www.effectivehealthcare.ahrq.gov/ reports/final.cfm. Accessed April 2, 2013.

2. Hoff T, Weller W, Depuccio M. The patient-centered medical home: a review of recent research. Med Care Res Rev. 2012;69(6):619-644.

3. Nielsen M, Langner B, Zema C, Hacker T, Grundy P. Benefits of Implementing the Primary Care Patient-Centered Medical Home: $A$ Review of Cost \& Quality Results, 2012. Washington, DC: PatientCentered Primary Care Collaborative, 2012. http://www.pcpcc.net/ files/benefits_of_implementing_the_primary_care_pcmh_0.pdf. Accessed November 17, 2012
4. Cherry DK, Hing E, Woodwell DA, Rechtsteiner EA. National Ambulatory Medical Care Survey: 2006 summary. Hyattsville, MD: National Center for Health Statistics; 2008. National Health Statistics Reports, No. 3.

5. Rittenhouse DR, Casalino LP, Shortell SM, et al. Small and mediumsize physician practices use few patient-centered medical home processes. Health Aff (Millwood). 2011;30(8):1575-1584

6. Solberg LI. Improving medical practice: a conceptual framework. Ann Fam Med. 2007;5(3):251-256.

7. Miller $W L$, Crabtree $B F$, Nutting $P A$, Stange $K C$, Jaén $C R$. Primary care practice development: a relationship-centered approach. Ann Fam Med. 2010;8(Suppl 1):S68-S79, S92.

8. Berenson RA, Hammons T, Gans DN, et al. A house is not a home: keeping patients at the center of practice redesign. Health Aff (Millwood). 2008;27(5):1219-1230

9. Solberg LI, Asche SE, Margolis KL, Whitebird RR. Measuring an organization's ability to manage change: the change process capability questionnaire and its use for improving depression care. Am J Med Qual. 2008;23(3):193-200.

10. Bodenheimer T, Wagner EH, Grumbach K. Improving primary care for patients with chronic illness: the chronic care model, Part 2. JAMA. 2002;288(15):1909-1914.

11. Hroscikoski MC, Solberg LI, Sperl-Hillen JM, Harper PG, McGrail MP, Crabtree BF. Challenges of change: a qualitative study of chronic care model implementation. Ann Fam Med. 2006;4(4):317-326.

12. Solberg LI, Hroscikoski MC, Sperl-Hillen JM, Harper PG, Crabtree BF. Transforming medical care: case study of an exemplary, small medical group. Ann Fam Med. 2006;4(2):109-116.

13. Nutting PA, Miller WL, Crabtree BF, Jaen $C R$, Stewart EE, Stange $\mathrm{KC}$. Initial lessons from the first national demonstration project on practice transformation to a patient-centered medical home. Ann Fam Med. 2009;7(3):254-260.

14. Nutting PA, Crabtree BF, Miller WL, Stange KC, Stewart EE, Jaén CR. Transforming physician practices to patient-centered medical homes: lessons from the National Demonstration Project. Health Aff (Millwood). 2011;30(3):439-445.

15. Homer CJ, Baron RJ. How to scale up primary care transformation: what we know and what we need to know? J Gen Intern Med. 2010;25(6):625-629.

16. National Committee for Quality Assurance. Standards and Guidelines for the Physician Practice Connections-Patient-Centered Medical Home. Washington, DC: National Committee for Quality Assurance; 2008.

17. Scholle SH, Torda P, Peikes D, Han E, Genevro J. Engaging Patients and Families in the Medical Home. (Prepared by Mathematica Policy Research under Contract No. HHSA290200900019I TO2.) Rockville, MD: Agency for Healthcare Research and Quality; 2010. AHRQ publication 10-0083-EF. 